\title{
Fatty Acid Composition of Adipose Tissue Triglycerides After Weight Loss and Weight Maintenance: the DIOGENES Study
}

\author{
M. KUNEŠOVÁ ${ }^{1,2}$, P. HLAVATÝ ${ }^{1}$, E. TVRZICKÁ ${ }^{2}$, B. STAŇKOVÁ ${ }^{2}$, P. KALOUSKOVÁ ${ }^{1}$, \\ N. VIGUERIE ${ }^{3}$, T. M. LARSEN ${ }^{4}$, M. A. VAN BAAK ${ }^{5}$, S. A. JEBB ${ }^{6}$, J. A. MARTINEZ ${ }^{7}$, \\ A. F. H. PFEIFFER ${ }^{8}$, A. KAFATOS ${ }^{9}$, T. HANDJIEVA-DARLENSKA ${ }^{10}$, M. HILL ${ }^{1}$, \\ D. LANGIN ${ }^{3}$, A. ŽÁK ${ }^{2}$, A. ASTRUP ${ }^{4}$, W. H. M. SARIS ${ }^{5}$
}

${ }^{1}$ Obesity Management Centre, Institute of Endocrinology, Prague, Czech Republic, ${ }^{2}$ Fourth Department of Medicine, First Medical Faculty, Charles University, Prague, Czech Republic, ${ }^{3}$ Obesity Research Laboratory, Institute of Metabolic and Cardiovascular Medicine, Inserm UMR1048, University of Toulouse, Toulouse University Hospitals, France, ${ }^{4}$ Department of Human Nutrition, Faculty of Life Sciences, University of Copenhagen, Denmark, ${ }^{5}$ Department of Human Biology, NUTRIM School for Nutrition, Toxicology and Metabolism, Maastricht University Medical Centre, Netherlands, ${ }^{6}$ MRC Human Nutrition Research, Elsie Widdowson Laboratory, Cambridge, United Kingdom, ${ }^{7}$ Department of Physiology and Nutrition, University of Navarra, Pamplona, Spain, ${ }^{8}$ Department of Clinical Nutrition, German Institute of Human Nutrition Potsdam-Rehbruecke, Nuthetal, Germany and Charité Universitätsmedizin Berlin, Department of Endocrinology, Diabetes and Nutrition, Berlin, Germany, ${ }^{9}$ Department of Social Medicine, Preventive Medicine \& Nutrition Clinic, University of Crete, Heraklion, Crete, Greece, ${ }^{10}$ Department of Human Nutrition, Dietetics and Metabolic Diseases, National Multiprofile Transport Hospital, Sofia, Bulgaria

Received May 22, 2012

Accepted June 27, 2012

On-line October 25, 2012

\section{Summary}

Fatty acid composition of adipose tissue changes with weight loss. Palmitoleic acid as a possible marker of endogenous lipogenesis or its functions as a lipokine are under debate. Objective was to assess the predictive role of adipose triglycerides fatty acids in weight maintenance in participants of the DIOGENES dietary intervention study. After an 8-week low calorie diet (LCD) subjects with > $8 \%$ weight loss were randomized to 5 ad libitum weight maintenance diets for 6 months: low protein (P)/low glycemic index (GI) (LP/LGI), low P/high GI (LP/HGI), high P/low GI (HP/LGI), high P/high GI $(\mathrm{HP} / \mathrm{HGI})$, and a control diet. Fatty acid composition in adipose tissue triglycerides was determined by gas chromatography in 195 subjects before the LCD (baseline), after LCD and weight maintenance. Weight change after the maintenance phase was positively correlated with baseline adipose palmitoleic (16:1n-7), myristoleic (14:1n-5) and trans-palmitoleic acid (16:1n-7t). Negative correlation was found with baseline oleic acid (18:1n-9).
Lower baseline monounsaturated fatty acids (14:1n-5, 16:1n-7 and trans $16: 1 n-7)$ in adipose tissue triglycerides predict better weight maintenance. Lower oleic acid predicts lower weight decrease. These findings suggest a specific role of monounsaturated fatty acids in weight management and as weight change predictors.

\section{Key words}

Diet • Palmitoleic acid • Fatty acids • Adipose tissue • Obesity management

\section{Corresponding author}

M. Kunešová, Institute of Endocrinology, Národní 8, 11694 Prague 1, Czech Republic. Fax: +420 224905105. E-mail: mkunesova@endo.cz 


\section{Introduction}

The fatty acid composition of adipose tissue reflects dietary fatty acid intake and also endogenous processing of fat, i.e. lipolysis and endogenous lipogenesis. Associations between obesity, diabetes mellitus and insulin sensitivity with specific patterns of fatty acid composition of serum phospholipids (Pelikánová et al. 2001, Zák et al. 2007, Huang et al. 2010), muscle membrane phospholipids (Borkman et al. 1993, Baur et al. 1999), skeletal muscle triglycerides (Manco et al. 2000), erythrocyte phospholipids (Ntali et al. 2011) and adipose tissue triglycerides (Iggman et al. 2010) have been reported. Endothelial dysfunction in type 2 diabetics has also been related to fatty acid composition; saturated fatty acids were related to endothelial dysfunction, while polyunsaturated fatty acids (PUFA) showed protective effects (Perassolo et al. 2008). A higher proportion of saturated fatty acids in serum phospholipids seemed to be related to insulin resistance while higher levels of polyunsaturated fatty acids are related to increased insulin sensitivity (Pelikánová et al. 2001). Recent studies brought evidence for varying relationships of individual saturated fatty acids to insulin sensitivity and obesity (Sampath and Ntambi 2005, Iggman et al. 2010).

Previously, we found that palmitoleic acid (16:1n-7) in serum cholesteryl esters and adipose tissue triglycerides correlated with multiple measures of adiposity and adipose tissue distribution (Kunešová et al. 2002a). Palmitoleic acid is the product of desaturation of palmitic acid (16:0) by stearoyl CoA desaturase 1 (delta-9 desaturase, SCD1). In monozygotic twins, before and after weight loss followed by one year weight maintenance, highly significant intrapair resemblance of palmitoleic acid percentage in all serum lipid classes (cholesteryl esters, phospholipids and triglycerides) and in adipose tissue triglycerides were found independently of dietary fat intake. This result suggests palmitoleic acid as a metabolic indicator under genetic control reflecting endogenous lipogenesis (Kunešová et al. 2002a,b). In experimental studies palmitoleic acid was suggested as a possible "lipokine" that allows adipose tissue to communicate with distant organs (Cao et al. 2008). However, this lipokine function was not confirmed by other authors, who showed that adipose tissue palmitoleic acid corresponds to endogenous lipogenesis (Hertzel et al. 2006, Gong et al. 2011). On the contrary, circulating palmitoleic acid in serum free fatty acids strongly and independently predicted insulin sensitivity in subjects at increased risk of type 2 diabetes (Stefan et al. 2010). Interestingly, trans-palmitoleic acid in serum phospholipids, which represents fatty acid mostly received from exogenous sources, was associated with slightly lower adiposity and independently associated with significantly lower insulin resistance (Mozaffarian et al. 2010).

To investigate the role of protein and glycemic index of carbohydrates in the weight maintenance after weight loss, the multicentre Pan European DIOGENES dietary intervention study was performed. Overweight and obese subjects started an eight weeks weight loss period using a low calorie formula diet (LCD 3.2 MJ per day). Only subjects with at least $8 \%$ loss of initial weight were eligible to start the weight maintenance phase lasting 6 months. For this period the subjects were randomized to five groups with different dietary protein content and glycemic index. Energy intake during weight maintenance period was ad libitum. The DIOGENES dietary intervention is part of the European integrated project on Diet, Obesity and genes (DIOGENES, www.diogenes-eu.org) (Saris and Harper 2005). The study was performed in 8 European centers and the results of the 6 months weight maintenance period were published recently (Larsen et al. 2010).

The aim of this part of the DIOGENES project was to assess the fatty acid composition of adipose tissue triglycerides at baseline, after 8 weeks of LCD and after 6 months of weight maintenance and to evaluate their change during this period. The second aim was to evaluate the baseline levels of adipose tissue fatty acids as possible predictors of weight change, change in body fat distribution and body composition during the weight loss and maintenance period.

\section{Material and Methods}

\section{Subjects and study design}

Subjects examined in this study were participants of the DIOGENES project in which adipose tissue biopsies were performed before the start of the study, after the LCD period and after the 6-month weight maintenance period. Fatty acid composition of AT triglycerides was analyzed and necessary clinical data were available. This subgroup of the total DIOGENES cohort was selected from 8 centers depending on the availability of the fat biopsies for fatty acid analysis. Baseline characteristics of the subjects and effect of the 
low calorie diet and weight maintenance period are given in Table 1.

The study protocol, methods, procedures and data processing have been described previously (Larsen et al. 2009, 2010, www.diogenes-eu.org) as well as the dietary intervention (Moore et al. 2009). Briefly, the subjects were screened and a baseline examination was performed (clinical investigation day 1, CID 1). The subjects then started the weight loss phase following a LCD 3.2 MJ/day (Modifast, Nutrition et Santé, France) supplemented with up to $400 \mathrm{~g} / \mathrm{d}$ of vegetables. At the end of the LCD period, they were examined again (CID2). Subjects who reached a weight loss $\geq 8 \%$ of their initial body weight were randomized to one of the following diets: low protein, low glycemic index (LPLGI), low protein high glycemic index (LPHGI), high protein low glycemic index (HPLGI), high protein high glycemic index (HPHGI) and control diet (C) given the relevant national dietary guidelines. They were instructed to follow the ad libitum randomized diet for six months. Following the 6 months weight maintenance period the subjects were examined again (CID 3). Fasting blood samples were drawn at each of the 3 CIDs for the analysis of blood metabolites. Samples of subcutaneous adipose tissue were obtained from the periumbilical area by needle aspiration under local anesthesia following an overnight fast at each of the time points. All procedures were standardized between study centers across Europe, and biopsy samples were stored at $-80{ }^{\circ} \mathrm{C}$ until analysis. The lipid fraction was extracted from the fat cake during RNA extraction by using the RNeasy total RNA Mini kit (Qiagen) (Márquez-Quiñones et al. 2010). The values of the anthropometric and laboratory parameters are marked 1,2 and 3 according to CID in which they were obtained.

Table 1. Characteristics of subjects before the treatment and after LCD and weight maintenance phase.

\begin{tabular}{lccc}
\hline Variable & Before & LCD & Weight maintenance \\
\hline Age & $42.05 \pm 5.61$ & & \\
Weight $(\mathrm{kg})$ & $96.67 \pm 15.53$ & $85.67 \pm 13.79^{*}$ & $86.99 \pm 14.47^{*}$ \\
Height $(\mathrm{m})$ & $1.69 \pm 0.09$ & & $30.22 \pm 4.25^{*+}$ \\
BMI & $33.57 \pm 4.41$ & $29.84 \pm 4.06^{*}$ & $96.55 \pm 11.47^{*}$ \\
Waist $(\mathrm{cm})$ & $105.46 \pm 12.06$ & $95.70 \pm 11.79^{*}$ & $108.88 \pm 9.88^{*}$ \\
Hip $(\mathrm{cm})$ & $115.71 \pm 10.17$ & $108.16 \pm 9.68^{*}$ & $21.70 \pm 6.45^{*}$ \\
SAD $(\mathrm{cm})$ & $24.61 \pm 3.73$ & $21.44 \pm 3.33^{*}$ & $120.63 \pm 13.59^{*+}$ \\
SBP $(\mathrm{mm} \mathrm{Hg})$ & $123.27 \pm 13.74$ & $116.16 \pm 13.44^{*}$ & $73.22 \pm 10.78^{*}+$ \\
DBP $(\mathrm{mm} \mathrm{Hg})$ & $75.63 \pm 10.39$ & $71.78 \pm 10.12^{*}$ & $30.50 \pm 10.52^{*}$ \\
FM $(\mathrm{kg})$ & $38.19 \pm 10.64$ & $30.12 \pm 10.50^{*}$ & $34.85 \pm 9.44^{*}$ \\
FM $(\%)$ & $39.44 \pm 8.25$ & $34.87 \pm 10.08^{*}$ & \\
\hline
\end{tabular}

$\mathrm{n}=195$, mean \pm S.D., $* \mathrm{p}<0.05$ in comparison with basal level, $+\mathrm{p}<0.05$ in comparison with LCD level.

\section{Fatty acid composition}

Analysis of the fatty acid composition of the lipid fraction consisting of adipose tissue triglycerides was performed by gas chromatography. Total lipid was transmethylated to fatty acid methyl esters (FAME) with $1 \mathrm{M}$ sodium methoxide in dry methanol under nitrogen atmosphere in darkness $(60 \mathrm{~min}$ at laboratory temperature). The reaction mixture was neutralized with $1 \mathrm{M}$ acetic acid, FAME were extracted twice into hexane and passed through a column $(5 \times 20 \mathrm{~mm})$ of anhydrous sodium sulphate. The combined extracts were dried under nitrogen, dissolved in an appropriate volume of isooctane and stored at $-20{ }^{\circ} \mathrm{C}$ until analyzed. Gas chromatography was performed with a Trace GC (Thermo Finnigan, USA) gas chromatograph equipped with a capillary split/splitless injector and flame-ionization detector (FID), combined with AS 2000 autosampler (Thermo Finnigan). Analyses of FAME were performed on fusedsilica capillary columns coated with chemically bonded stationary phases Select FAME (100 m x $0.32 \mathrm{~mm}$ I.D.) (Varian, the Netherlands). The oven temperature was programmed from $80^{\circ} \mathrm{C}$ to $260{ }^{\circ} \mathrm{C}$ at a rate $2^{\circ} \mathrm{C} / \mathrm{min}$, then isothermal $25 \mathrm{~min}$. The injector and detector temperatures were 250 and $270{ }^{\circ} \mathrm{C}$, respectively. Hydrogen carrier gas was maintained at a head pressure of $70 \mathrm{kPa}$ and total flow $25 \mathrm{ml} / \mathrm{min}$. Integration software 
Table 2. Percentage of fatty acids in adipose triglycerides during the weight management.

\begin{tabular}{|c|c|c|c|}
\hline Variable & Before & LCD & Weight maintenance \\
\hline $12: 0$ & $0.29 \pm 0.01$ & $0.25 \pm 0.009^{*}$ & $0.30 \pm 0.01+$ \\
\hline 14:0 & $2.57 \pm 0.04$ & $2.36 \pm 0.04 *$ & $2.44 \pm 0.05^{*}+$ \\
\hline $14: \ln 5$ & $0.26 \pm 0.007$ & $0.23 \pm 0.006^{*}$ & $0.24 \pm 0.007 *+$ \\
\hline 16:0 & $23.26 \pm 0.15$ & $22.73 \pm 0.15^{*}$ & $22.58 \pm 0.15^{*}$ \\
\hline $16: 1 n-7 c$ & $4.57 \pm 0.09$ & $4.23 \pm 0.09 *$ & $4.25 \pm 0.09 *$ \\
\hline $16: 1 n-7 t$ & $0.032 \pm 0.001$ & $0.028 \pm 0.001 *$ & $0.027 \pm 0.001 *+$ \\
\hline $16: 1 n-9$ & $0.66 \pm 0.007$ & $0.70 \pm 0.006^{*}$ & $0.67 \pm 0.007 *+$ \\
\hline $18: 0$ & $3.79 \pm 0.06$ & $3.85 \pm 0.05$ & $3.98 \pm 0.06^{*}$ \\
\hline $18: \ln -7 c$ & $1.91 \pm 0.02$ & $1.89 \pm 0.03$ & $1.86 \pm 0.02$ \\
\hline $18: \ln -9 c$ & $46.14 \pm 0.22$ & $47.15 \pm 0.22 *$ & $46.82 \pm 0.23^{*}+$ \\
\hline $18: 1 n-9$ sum $t$ & $1.03 \pm 0.03$ & $1.04 \pm 0.02$ & $1.03 \pm 0.02$ \\
\hline $18: 2 n-6 c c$ & $12.45 \pm 0.15$ & $12.44 \pm 0.16$ & $12.66 \pm 0.15^{*+}$ \\
\hline $18: 2 n-6 t t$ & $0.013 \pm 0.0007$ & $0.011 \pm 0.0005^{*}$ & $0.011 \pm 0.0005^{*}$ \\
\hline $18: 2 n-6 t c$ & $0.10 \pm 0.005$ & $0.092 \pm 0.005^{*}$ & $0.097 \pm 0.006^{*}$ \\
\hline $18: 2 n-6 c t$ & $0.047 \pm 0.002$ & $0.038 \pm 0.002 *$ & $0.036 \pm 0.002 *$ \\
\hline $18: 3 n-6 a l c$ & $0.05 \pm 0.002$ & $0.05 \pm 0.001$ & $0.05 \pm 0.002+$ \\
\hline $18: 3 n-3 a l c$ & $0.47 \pm 0.02$ & $0.41 \pm 0.02 *$ & $0.42 \pm 0.02+$ \\
\hline $20: 0$ & $0.35 \pm 0.02$ & $0.31 \pm 0.02$ & $0.34 \pm 0.02$ \\
\hline $20: 1 n-9 c$ & $0.63 \pm 0.008$ & $0.69 \pm 0.009^{*}$ & $0.70 \pm 0.008^{*}$ \\
\hline $20: 2 n-6 c c$ & $0.19 \pm 0.003$ & $0.21 \pm 0.004^{*}$ & $0.20 \pm 0.003^{*}$ \\
\hline $20: 3 n-9 a l c$ & $0.024 \pm 0.0009$ & $0.026 \pm 0.0009$ & $0.026 \pm 0.001$ \\
\hline $20: 3 n-6 a l c$ & $0.24 \pm 0.006$ & $0.27 \pm 0.006^{*}$ & $0.26 \pm 0.006^{*}+$ \\
\hline $20: 4 n-6 a l c$ & $0.41 \pm 0.007$ & $0.44 \pm 0.008^{*}$ & $0.44 \pm 0.008^{*}$ \\
\hline $20: 5 n-3 a l c$ & $0.06 \pm 0.002$ & $0.05 \pm 0.002$ & $0.06 \pm 0.003$ \\
\hline $22: 4 n-6 a l c$ & $0.14 \pm 0.004$ & $0.16 \pm 0.004 *$ & $0.16 \pm 0.003 *$ \\
\hline $22: 5 n-6 a l c$ & $0.035 \pm 0.0002$ & $0.036 \pm 0.001$ & $0.029 \pm 0.001 *+$ \\
\hline $22: 5 n-3 a l c$ & $0.15 \pm 0.004$ & $0.17 \pm 0.004 *$ & $0.17 \pm 0.004^{*}$ \\
\hline $22: 6 n-3 a l c$ & $0.11 \pm 0.003$ & $0.11 \pm 0.004$ & $0.13 \pm 0.004^{*}+$ \\
\hline$S F A$ & $30.12 \pm 0.22$ & $29.39 \pm 0.21 *$ & $29.51 \pm 0.22^{*}$ \\
\hline$M F A$ & $54.18 \pm 0.22$ & $54.91 \pm 0.23 *$ & $54.55 \pm 0.23+$ \\
\hline$T F A$ & $1.23 \pm 0.03$ & $1.21 \pm 0.02$ & $1.20 \pm 0.03$ \\
\hline PUFAn-6 & $13.51 \pm 0.15$ & $13.61 \pm 0.02$ & $13.8 \pm 0.16^{*}+$ \\
\hline PUFAn-3 & $0.93 \pm 0.02$ & $0.86 \pm 0.02 *$ & $0.91 \pm 0.02+$ \\
\hline $16: 1 n-7 / 16: 0$ & $0.20 \pm 0.004$ & $0.19 \pm 0.004$ & $0.19 \pm 0.003$ \\
\hline $18: \ln -9 c / 18: 0$ & $12.76 \pm 0.23$ & $12.82 \pm 0.24$ & $12.28 \pm 0.22$ \\
\hline
\end{tabular}

\# mean \pm S.E., $*$ p $<0.05$ in comparison with basal level, $+p<0.05$ in comparison with LCD level.

Clarity for Windows ${ }^{\circledR}$ (Data Apex ${ }^{\circledR}$ Ltd., Praha) was used for data acquisition and handling. Ratios 16:1n-7/16:0 and 18:1n-9/18:0 were used as measures of SCD activity because they reflect stearoyl CoA gene expression (SCD, delta-9 desaturase, Sjögren et al. 2007).

\section{Statistical methods}

The data were evaluated by repeated measures
ANOVA with Bonferroni correction. To eliminate skewed data distribution and heteroscedasticity, the original data was transformed to a Gaussian distribution by a Box-Cox transformation before further processing using the statistical software Statgraphics Centurion, version XVI from Statpoint Inc. (Herndon, Virginia, USA).

The relationships between change of anthropometric characteristics (matrix $\mathbf{Y}$ ) and their initial 
Table 3. Relationships between weight change (weight3 - weight 1 ), (explained variable) and baseline fatty acid composition and anthropometrical traits (explanatory variables) evaluated using multivariate regression with reduction of dimensionality (model of Orthogonal Projections to Latent Structures, OPLS).

\section{Component of weight loss}

Explained variability $=13 \%(10.9 \%)$

\begin{tabular}{|c|c|c|c|c|c|c|}
\hline & \multirow{2}{*}{ Variable } & \multicolumn{5}{|c|}{ Explained variability $=13 \%(10.9 \%)$} \\
\hline & & Parameter $^{\mathrm{a}}$ & $95 \% \mathrm{CI}^{\mathrm{b}}$ & $99 \%$ CI & $\begin{array}{c}\text { Parameter/ } \\
95 \% \mathrm{CI}^{\mathrm{b}}\end{array}$ & $\mathrm{R}^{\mathrm{c}}$ \\
\hline$X$ & Weight1 & -0.514 & 0.093 & 0.147 & -5.54 & $-0.816^{* *}$ \\
\hline$X$ & BMII & -0.501 & 0.068 & 0.107 & -7.41 & $-0.795 * *$ \\
\hline$X$ & Waist1 & -0.525 & 0.027 & 0.043 & -19.37 & $-0.833 * *$ \\
\hline$X$ & FA14ln51 & 0.278 & 0.069 & 0.109 & 4.05 & $0.442 * *$ \\
\hline$X$ & $F A 16 \ln 7 t 1$ & 0.264 & 0.131 & 0.207 & 2.01 & $0.418 * *$ \\
\hline$X$ & FA161n71 & 0.202 & 0.103 & 0.163 & 1.96 & $0.321 * *$ \\
\hline$X$ & $F A 18 \ln 9 c 1$ & -0.241 & 0.114 & 0.181 & -2.11 & $-0.383 * *$ \\
\hline $\boldsymbol{Y}$ & Weight3 - weight 1 & 1.000 & 0.330 & 0.522 & 3.03 & $0.361 * *$ \\
\hline
\end{tabular}

a...component loadings for the predictive components expressed as regression coefficients; b...confidence interval; c...component loadings for the predictive components expressed as correlation coefficients of individual variables with the predictive components.

values and initial values of fatty acids and further laboratory data (matrix $\mathbf{X}$ ) were simultaneously evaluated using multivariate regression with reduction of dimensionality, known as bidirectional orthogonal projections to latent structures (O2PLS). The data transformed by Box-Cox transformations underwent processing by O2PLS method (Trygg and Wold 2002, Trygg et al. 2007, Hill et al. 2010). In contrast to ordinary multivariate regression or multiple regression, O2PLS is effective in coping with the problem of severe multicollinearity within the $\mathbf{X}$ and within the $\mathbf{Y}$ (see Table 3). The aforementioned model enabled us to find the variables with high predictive value for description of relationships between $\mathbf{X}$ and $\mathbf{Y}$ and to find a structure of these relationships.

We have tested the relevance of individual variables for the model using a criterion Variable Importance (VIP). Only the variables that showed significant relevance for the first and/or the second predictive component were included in the model. Similarly, the relevant number of predictive components was tested using a criterion Prediction Error Sum of Squares (PRESS).

The statistical software SIMCA-P+ Version 12.0.0.0 from UmetricsAB (Umeå, Sweden) was used for data analysis. The software enabled us to find the number of the relevant components utilizing the prediction error sum of squares and also allowed the detection of multivariate non-homogeneities and testing the multivariate normal distribution and homoscedasticity (homogeneity of variance).

Relationships between two variables were evaluated by Spearman's correlations.

Due to significant heterogeneity in weight loss between the eight centers - in the Bulgarian group during the weight maintenance period significant higher weight loss was found in comparison with the other seven centers $(\mathrm{p}<0.001)$ - we excluded this center from analysis in this study.

\section{Ethics}

The study was approved by the local ethics committees in the respective countries. The protocol was in accordance with the Declaration of Helsinki (2009), all study participants signed an informed consent document after verbal and written instructions and according to local legislation.

\section{Results}

Changes in percentage of individual fatty acids in adipose tissue triglycerides are shown in Table 2 . In comparison with baseline values, decreases in saturated (myristic 14:0 and palmitic 16:0), and monounsaturated fatty acids (myrimyristoleic 14:1n-5 and palmitoleic acid 16:1n-7) were found after LCD and weight maintenance period and in trans-linoleic acids (18:2 n-6tt,ct and tc) after weight maintenance. Significant increases were 


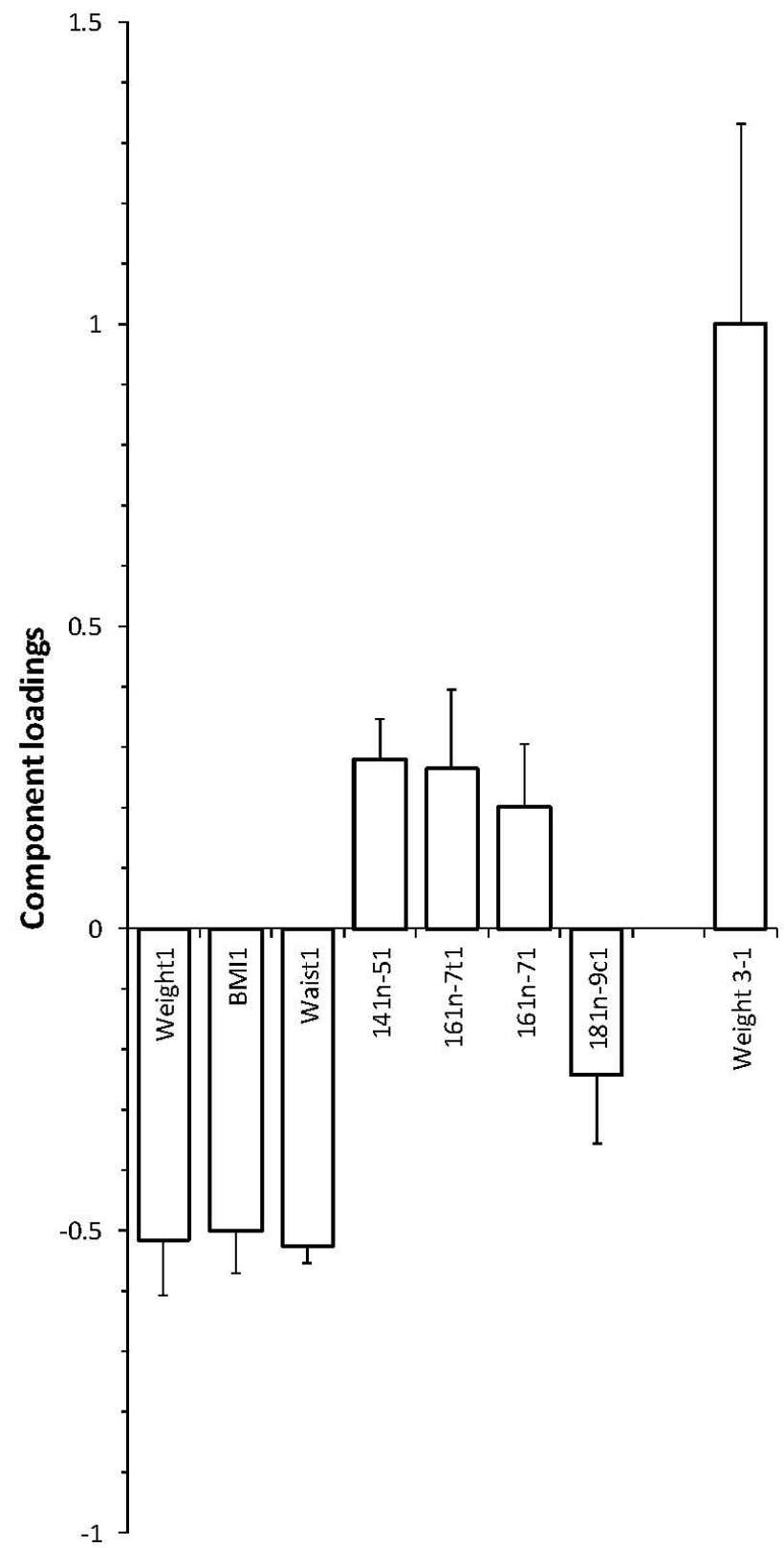

Fig. 1. Relationships between change in weight (matrix $Y$ ) and basal anthropometry and adipose triglyceride fatty acid composition (matrix X). 1 initial values, 3-1 difference between weight maintenance and initial value.

found in oleic acid (18:1n-9) and stearic (18:0) acid after weight maintenance, in oleic acid also after LCD. Increases were shown in n-6 PUFA's - linoleic (18:2n-6cc), dihomo-gamma-linoleic (20:3n-6), arachidonic acid (20:4n-6) and docosatetrenoic acid (22:4n-6), and in n-3 PUFA's eicosapentenoic (EPA, 22:5n-3) after LCD and weight maintenance and in docosahexenoic (DHA,22:6n-3) after weight maintenance only.

When evaluating percentages of adipose tissue fatty acids at baseline (CID1) as predictors of weight change after the weight management (CID3-CID1) we found that only myristoleic $(14: 1 \mathrm{n}-5)$, palmitoleic (16:1n-7) and trans-palmitoleic (16:1n-7 t) acids were significantly positively correlated with weight loss, i.e. the lower the initial percentage the greater was the weight loss. Percentage of oleic acid (18:1n-9) correlated negatively with weight loss as well as previously shown initial weight and BMI and waist (Handjieva-Darlenska et al. 2010) (Table 3, Fig. 1). The variability of the weight loss (dependent variable) explained by independent variables (initial fatty acids and anthropometrical traits) was $13.0 \%$ (10.9\% after cross-validation).

Spearman rank correlations show significant positive association of weight and waist changes after weight maintenance with basal sum of saturated fatty acids, negative correlation with basal sum of monounsaturated fatty acids and SCD activity, expressed as ratio $18: 1 n-9 / 18: 0$, the correlation with $16: 1 n-7 / 16: 0$ was not significant. Trans fatty acids correlated positively with weight change only (Table 4).

The effect of protein quantity in the diet and of glycemic index of the diet will be evaluated elsewhere.

Table 4. Spearman rank correlations between basal percentage of fatty acids in adipose triglycerides and change in weight and waist after weight maintenance period.

Fatty acid Weight 3 - weight 2 Waist 3 - waist 2

\begin{tabular}{lcccc}
\hline Basal values & $\mathrm{r}$ & $\mathrm{P}$ & $\mathrm{r}$ & $\mathrm{P}$ \\
SFA & 0.22 & 0.003 & 0.28 & 0.001 \\
MFA & -0.22 & 0.002 & -0.29 & 0.001 \\
TFA & 0.21 & 0.003 & 0.09 & $\mathrm{NS}$ \\
$16: 1 n-7 / 16: 0$ & -0.001 & $\mathrm{NS}$ & -0.04 & $\mathrm{NS}$ \\
$18: 1 n-9 c / 18: 0$ & -0.16 & 0.02 & -0.16 & 0.02 \\
\hline
\end{tabular}

Values 2 after low calorie diet. Values 3 after weight maintenance.

\section{Discussion}

In the DIOGENES group of subjects we found significant positive correlations between total weight loss with percentage of myristoleic (14:1n-5), palmitoleic (16:1n-7) and trans-palmitoleic acid (16:1n-7t) in adipose tissue triglycerides at baseline. This outcome in agreement with previous findings suggests that palmitoleic acid levels in adipose tissue reflect endogenous lipogenesis (Kunešová et al. 2002a, Hertzel 
et al. 2006, Gong et al. 2011). Also myristoleic acid (product of desaturation of myristic acid in humans), a minor fatty acid in adipose tissue, seems to be an indicator of endogenous lipogenesis (Lands 1995). This observation is in agreement with a study in 1926 subjects in which a positive association between adipose tissue palmitoleic acid concentrations and adipose tissue desaturation indices with obesity was shown (Gong et al. 2011). In elderly men, a negative correlation of insulin sensitivity with dietary and adipose tissue palmitic and palmitoleic acid and some PUFA's (20:3n-6, 20:4n-6, $22: 4 n-6,22: 5 n-3$ and 22:6n-3) was shown. In this group, insulin sensitivity positively correlated with lauric (12:0), myristic (14:0), margaric (17:0) and stearic (18:0) acids and essential fatty acids linoleic acid (18:2n-6) and alpha linolenic acid (18:3n-3). Most associations were diminished or disappeared in lean individuals, indicating a role of obesity (Iggman et al. 2010). A high proportion of palmitoleic acid in serum cholesteryl esters independently predicted high plasma glucose concentrations after 5 year follow-up in Amerindian women (Lindgärde et al. 2006).

The lipogenic capacity of human adipose tissue is lower than in rats (Letexier et al. 2003) and de novo lipogenesis is highly regulated, for review see (Strable and Ntambi 2010). In mice with modified FABP expression a relation between palmitoleate and de novo lipogenesis and SCD activity has been shown. In adipose tissue of adipose-FABP null mice increased de novo lipogenesis was associated with enhanced levels of palmitic acid and palmitoleic acid and increased fat mass (Hertzel et al. 2006). In mice with FABP (aP2 and mall) mutations characterized by resistance to diet-induced obesity and metabolic syndrome significantly enhanced insulin receptor signaling, enhanced muscle AMPactivated kinase (AMP-K) activity, and reduced liver SCD activity were found (Maeda et al. 2005). These studies show close relationship of palmitate and palmitoleate levels with endogenous lipogenesis in mice adipose tissue and in liver.

As shown in recent reviews (Flowers and Ntambi 2008, Paton and Ntambi 2008), scd1-deficient mice have reduced lipid synthesis and enhanced lipid oxidation, thermogenesis and insulin sensitivity in various tissues including liver, muscle and adipose tissue. SCD 1 is required for protection against dietary unsaturated fat deficiency, leptin deficiency-induced diabetes, and palmitate-induced lipotoxic insults in muscle and pancreatic beta-cells. In obesity, starvation and exercise increased muscle SCD1.

In humans, an association of delta-9 desaturase activity with adiposity and plasma lipid profile was suggested in a group of healthy adolescent women; this supports the assumption that delta-9 activity independently reflects higher body mass index and higher circulatory triglyceride levels (Zhou et al. 2009). We did not find a decrease in SCD1 activity calculated as ratios 16:1n-7/16:0 and 18:1n-9/18:0 in adipose tissue. This was in contrast to a study including a lifestyle intervention that found a significant decrease in total and saturated fat intake, a decrease in BMI and HOMA insulin resistance associated with a decrease in delta-9 desaturase (Corpeleijn et al. 2006).

The relationship between fatty acids reflecting endogenous lipogenesis and weight (a marker of total adipose tissue) was not related to waist circumference (a marker of abdominal fat). This could be related to the recently found greater enrichment of palmitoleic acid (16:1n-7) associated with higher expression of SCD1 and with higher content of SCD1-derived fatty acids in gluteofemoral adipose tissue (Pinnick et al. 2012).

In our study, we found that basal transpalmitoleic acid (trans 16:1n-7) was a negative predictor of weight loss. This is in contrast to a study showing that trans-palmitoleic acid correlates with slightly lower adiposity (Mozaffarian et al. 2010). The different result could be due to a weak association between dietary triglyceride fatty acids, which are predominantly saturated, and composition of fatty acids in adipose tissue triglycerides (Hodson et al. 2008).

At the end of the study, we found a significant decrease in proportion of the most saturated and monounsaturated fatty acids with exception of stearic acid (18:0) and oleic acid. Concurrently, we found a negative correlation of baseline oleic acid (18:1n-9) with total weight loss (the higher baseline oleic acid the higher weight loss). Oleic acid was shown to control the expression of SCD1 at the transcriptional level leading to a decrease in SCD1 mRNA content in human aortic smooth muscle cells (Minville-Walz et al. 2012). Oleic acid may exert a similar effect in adipose tissue. Stearic acid was shown to generate a lower lipemic response in comparison with palmitic and myristic acid, and also is a poor substrate for TG synthesis (Sampath and Ntambi 2005). Stearic acid exerts neutral effect also on cholesterol metabolism in comparison with saturated fatty acids with 12-16 carbons. These results are in agreement with a positive relationship of stearic acid to insulin 
sensitivity and negative to BMI (Roberts et al. 2009, Iggman et al. 2010). A lower decrease of stearic acid may also reflect a higher decrease in SCD activity. This precedes induction of other lipogenic genes and transcription factors as sterol regulatory element binding protein 1c (SREBP 1c), a key regulator of lipogenic gene transcription, carbohydrate response element binding protein (ChREBP) (Clark et al. 2002, Biddinger et al. 2005, Strable and Ntambi 2010) and peroxisome proliferator-activated receptor-gamma coactivator-1beta (PGC-1beta, Sampath et al. 2007). Insulin effect is mediated through SREBP 1c. Leptin (Hodson et al. 2008), glucagon (Lefevre et al. 1999) and AT II receptor blocker (Yokozawa et al. 2009) decrease SCD1 mRNA activity. The relationship of stearic acid content with insulin sensitivity (positive) and BMI (negative) could be mediated by adipocyte size, smaller adipocytes are more insulin sensitive. Roberts et al. (2009) have shown a strong positive relationship of adipose TG myristic and stearic acid with adipocyte size and insulin sensitivity (HOMA model) in humans. Lipogenic gene expression was shown to be inversely correlated with adipocyte cell size. Different regulation was proposed for adipose and hepatic de novo lipogenesis (Roberts et al. 2009). This is supported by a study showing up-regulation of SCD1 and enhancement of SCD activity in the liver of mice treated by rosiglitazone possibly in association with insulin sensitizing effect of thiazolidinediones (Kuda et al. 2009).

The consistent increase was found in this study in the percentage of n- 6 PUFA and to a lesser extent increases in long chain n-3 PUFA [(eicosapentenoic acid (20:5n-3), docosapentenoic (22:5n-3) and docosahaxenoic acid (22:6n-3)] which most likely reflects changes in dietary fat composition during the weight maintenance phase (Hlavaty et al. 2008).

Adipose tissue distribution was shown to be related to fatty acid composition. Specifically, central obesity was positively associated with n-6 polyunsaturated fatty acids and inversely associated with monounsaturated fatty acids and n-3 polyunsaturated fatty acids in adipose tissue (Phinney et al. 1994, Garaulet et al. 2001). We found a negative correlation of monounsaturated fatty acids and surprisingly also of SCD1 activity expressed as 18:1n-9/18:0, questioning usage of this ratio as reflection of SCD activity due to supposed higher role of exogenous sources of $\mathrm{C} 18$ acids, and a positive correlation of saturated fatty acids with change in weight and waist circumference.

In conclusion, higher baseline proportion of palmitoleic, myristoleic and trans-palmitoleic acids in adipose triglycerides predict less successful weight maintenance. Conversely, oleic acid percentage negatively predicts weight change. During the long term weight maintenance diet a favorable change in fatty acid composition including a decrease in most saturated and monounsaturated $(14: 1 \mathrm{n}-5,16: 1 \mathrm{n}-7,16: 1 \mathrm{n}-7 \mathrm{t})$ fatty acids was found concurrently with an increase in $n-6$ and to a lesser extent also in $\mathrm{n}-3$ polyunsaturated fatty acids.

\section{Conflict of Interest}

There is no conflict of interest.

\section{Acknowledgements}

This work was funded by grant IGA NS 9830-4 of Internal Grant Agency Ministry of Health and by EC contract no. FP6-2005-513946.

\section{References}

BAUR LA, CONNOR J, PAN DA, STORLIEN H: Relationship between maternal risk of insulin resistance and the child's muscle membrane fatty acid composition. Diabetes 48: 112-113, 1999.

BIDDINGER SB, ALMIND K, MIYAZAKI M, KOKKOTOU E, NTAMBI JM, KAHN CR: Effects of diet and genetic background on sterol regulatory element-binding protein-1c, stearoyl-CoA desaturase 1, and the development of the metabolic syndrome. Diabetes 54: 1314-1323, 2005.

BORKMAN M, STORLIEN LH, PAN DA, JENKINS AB, CHISHOLM DJ, CAMPBELL LV: The relation between insulin sensitivity and the fatty acid composition on skeletal muscle phospholipids. $N$ Engl J Med 328: 238244, 1993.

CAO H, GERHOLD K, MAYERS JR, WIEST MM, WATKINS SM, HOTAMISLIGIL GS: Identification of a lipokine, a lipid hormone linking adipose tissue to systemic metabolism. Cell 134: 933-944, 2008. 
CLARKE SD, GASPERIKOVA D, NELSON C, LAPILLONNE A, HEIRD WC: Fatty acid regulation of gene expression: a genomic explanation for the benefits of the mediterranean diet. Ann N Y Acad Sci 967: 283-298, 2002.

CORPELEIJN E, FESKENS EJ, JANSEN EH, MENSINK M, SARIS WH, DE BRUIN TW, BLAAK EE: Improvements in glucose tolerance and insulin sensitivity after lifestyle intervention are related to changes in serum fatty acid profile and desaturase activities: the SLIM study. Diabetologia 49: 2392-2401, 2006.

DECLARATION OF HELSINKI: Ethical principles for medical research involving human subjects. J Indian Med Assoc 107: 403-405, 2009.

FLOWERS MT, NTAMBI JM: Role of stearoyl-coenzyme A desaturase in regulating lipid metabolism. Curr Opin Lipidol 19: 248-256, 2008.

GARAULET M, PÉREZ-LLAMAS F, PÉREZ-AYALA M, MARTÍNEZ P, DE MEDINA FS, TEBAR FJ, ZAMORA $S$ : Site-specific differences in the fatty acid composition of abdominal adipose tissue in an obese population from a Mediterranean area: relation with dietary fatty acids, plasma lipid profile, serum insulin, and central obesity. Am J Clin Nutr 74: 585-591, 2001.

GONG J, CAMPOS H, MCGARVEY S, WU Z, GOLDBERG R, BAYLIN A: Adipose tissue palmitoleic acid and obesity in humans: does it behave as a lipokine? Am J Clin Nutr 93: 186-191, 2011.

HANDJIEVA-DARLENSKA T, HANDJIEV S, LARSEN TM, VAN BAAK MA, JEBB S, PAPADAKI A, PFEIFFER AF, MARTINEZ JA, KUNESOVA M, HOLST C, SARIS WH, ASTRUP A: Initial weight loss on an 800-kcal diet as a predictor of weight loss success after 8 weeks: the Diogenes study. Eur J Clin Nutr 64: 994-999, 2010.

HERTZEL AV, SMITH LA, BERG AH, CLINE GW, SHULMAN GI, SCHERER PE, BERNLOHR DA: Lipid metabolism and adipokine levels in fatty acid-binding protein null and transgenic mice. Am J Physiol Endocrinol Metab 290: E814-E823, 2006.

HILL M, PAŘÍZEK A, CIBULA D, KANCHEVA R, JIRÁSEK JE, JIRKOVSKÁ M, VELÍKOVÁ M, KUBÁTOVÁ J, KLÍMKOVÁ M, PAŠKOVÁ A, ŽIŽKA Z, KANCHEVA L, KAZIHNITKOVÁ H, ZAMRAZILOVÁ L, STÁRKA L: Steroid metabolome in plasma from the umbilical artery, umbilical vein, maternal cubital vein and in amniotic fluid in normal and preterm labor. J Steroid Biochem Mol Biol 121: 594-610, 2010.

HLAVATÝ P, KUNEŠOVÁ M, GOJOVÁ M, TVRZICKÁ E, VECKA M, ROUBAL P, HILL M, HLAVATÁ K, KALOUSKOVÁ P, HAINER V, ŽÁK A, DRBOHLAV J: Change in fatty acid composition of serum lipids in obese females after short-term weight-reducing regimen with the addition of n-3 long chain polyunsaturated fatty acids in comparison to controls. Physiol Res 57 (Suppl 1): S57-S65, 2008.

HODSON L, SKEAFF CM, FIELDING BA: Fatty acid composition of adipose tissue and blood in humans and its use as a biomarker of dietary intake. Prog Lipid Res 47: 348-380, 2008.

HUANG T, WAHLQVIST ML, XU T, XU A, ZHANG A, LI D: Increased plasma n-3 polyunsaturated fatty acid is associated with improved insulin sensitivity in type 2 diabetes in China. Mol Nutr Food Res 54 (Suppl 1): S112-S119, 2010.

IGGMAN D, ARNLÖV J, VESSBY B, CEDERHOLM T, SJÖGREN P, RISÉRUS U: Adipose tissue fatty acids and insulin sensitivity in elderly men. Diabetologia 53: 850-857, 2010.

KUDA O, STANKOVA B, TVRZICKA E, HENSLER M, JELENIK T, ROSSMEISL M, FLACHS P, KOPECKY J: Prominent role of liver in elevated plasma palmitoleate levels in response to rosiglitazone in mice fed high-fat diet. J Physiol Pharmacol 60: 135-140, 2009.

KUNEŠOVÁ M, HAINER V, TVRZICKA E, PHINNEY SD, ŠTICH V, PAŘÍZKOVÁ J, ŽÁK A, STUNKARD AJ: Assessment of dietary and genetic factors influencing serum and adipose fatty acid composition in obese female identical twins. Lipids 37: 27-32, 2002a.

KUNEŠOVÁ M, PHINNEY S, HAINER V, TVRZICKÁ E, ŠTICH V, PAŘÍZKOVÁ J, ŽÁK A, STUNKARD A: The responses of serum and adipose Fatty acids to a one-year weight reduction regimen in female obese monozygotic twins. Ann N Y Acad Sci 967: 311-323, 2002 b.

LANDS WE: Long-term fat intake and biomarkers. Am J Clin Nutr 61 (Suppl 3): 721S-725S, 1995. 
LARSEN TM, DALSKOV S, VAN BAAK M, JEBB S, KAFATOS A, PFEIFFER A, MARTINEZ JA, HANDJIEVADARLENSKA T, KUNESOVA M, HOLST C, SARIS WH, ASTRUP A: The Diet, Obesity and Genes (Diogenes) Dietary Study in eight European countries - a comprehensive design for long-term intervention. Obes Rev 11: 76-91, 2009.

LARSEN TM, DALSKOV SM, VAN BAAK M, JEBB SA, PAPADAKI A, PFEIFFER AF, MARTINEZ JA, HANDJIEVA-DARLENSKA T, KUNESOVA M, PIHLSGARD M, STENDER S, HOLST C, SARIS WH, ASTRUP A: Diets with high or low protein content and glycaemic index for weight-loss maintenance. N Engl J Med 363: 2102-2113, 2010.

LEFEVRE P, DIOT C, LEGRAND P, DOUAIRE M: Hormonal regulation of stearoyl coenzyme-A desaturase 1 activity and gene expression in primary cultures of chicken hepatocytes. Arch Biochem Biophys 368: 329-337, 1999.

LETEXIER D, PINTEUR C, LARGE V, FRÉRING V, BEYLOT M: Comparison of the expression and activity of the lipogenic pathway in human and rat adipose tissue. J Lipid Res 44: 2127-2134, 2003.

LINDGÄRDE F, VESSBY B, AHRÉN B: Serum cholesteryl fatty acid composition and plasma glucose concentrations in Amerindian women. Am J Clin Nutr 84: 1009-1013, 2006.

MAEDA K, CAO H, KONO K, GORGUN CZ, FURUHASHI M, UYSAL KT, CAO Q, ATSUMI G, MALONE H, KRISHNAN B, MINOKOSHI Y, KAHN BB, PARKER RA, HOTAMISLIGIL GS: Adipocyte/macrophage fatty acid binding proteins control integrated metabolit responses in obesity and diabetes. Cell Metab 1: $107-$ $119,2005$.

MANCO M, MINGRONE G, GRECO AV, CAPRISTO E, GNIULI D, DE GAETANO A, GASBARRINI G: Insulin resistance directly correlates with increased saturated fatty acids in skeletal muscle triglycerides. Metabolism 49: 220-224, 2000.

MÁRQUEZ-QUIÑONES A, MUTCH DM, DEBARD C, WANG P, COMBES M, ROUSSEL B, HOLST C, MARTINEZ JA, HANDJIEVA-DARLENSKA T, KALOUSKOVA P, JEBB S, BABALIS D, PFEIFFER AF, LARSEN TM, ASTRUP A, SARIS WH, MARIMAN E, CLÉMENT K, VIDAL H, LANGIN D, VIGUERIE N, DiOGenes Project: Adipose tissue transcriptome reflects variations between subjects with continued weight loss and subjects regaining weight 6 mo after caloric restriction independent of energy intake. Am J Clin Nutr 92: 975-984, 2010.

MINVILLE-WALZ M, GRESTI J, PICHON L, BELLENGER S, BELLENGER J, NARCE M, RIALLAND M: Distinct regulation of stearoyl-CoA desaturase 1 gene expression by cis and trans C18:1 fatty acids in human aortic smooth muscle cells. Genes Nutr 7: 209-216, 2012.

MOORE CS, LINDROOS AK, KREUTZER M, LARSEN TM, ASTRUP A, VAN BAAK MA, HANDJIEVADARLENSKA T, HLAVATY P, KAFATOS A, KOHL A, MARTINEZ JA, MONSHEIMER S, JEBB SA: Dietary strategy to manipulate ad libitum macronutrient intake, and glycaemic index, across eight European countries in the Diogenes Study. Obes Rev 11: 67-75, 2009.

MOZAFFARIAN D, CAO H, KING IB, LEMAITRE RN, SONG X, SISCOVICK DS, HOTAMISLIGIL GS: Transpalmitoleic acid, metabolic risk factors, and new-onset diabetes in U.S. adults: a cohort study. Ann Intern Med 153: 790-799, 2010.

NTALI G, KOUTSARI C, KARAKIKE K, MAKRAS P, SKOPOULI F, MC MILAN M, SLATER C, HIGGINS S, ZAMPELAS A, MALKOVA D: Erythrocyte fatty acid composition and insulin sensitivity in daughters of Type 2 diabetic patients and women with no family history of diabetes. J Endocrinol Invest 33: 306-312, 2010.

PATON CM, NTAMBI JM: Biochemical and physiological function of stearoyl-CoA desaturase. Am J Physiol Endocrinol Metab 297: E28-E37, 2009.

PELIKÁNOVÁ T, KAZDOVÁ L, CHVOJKOVÁ S, BASE J: Serum phospholipid fatty acid composition and insulin action in type 2 diabetic patients. Metabolism 50: 1472-1478, 2001.

PERASSOLO MS, ALMEIDA JC, STEEMBURGO T, DALL'ALBA V, DE MELlO VD, ZELMANOVITZ T, DE AZEVEDO MJ, GROSS JL: Endothelial dysfunction and serum fatty acid composition in patients with type 2 diabetes mellitus. Metabolism 57: 1167-1172, 2008.

PHINNEY SD, STERN JS, BURKE KE, TANG AB, MILLER G, HOLMAN RT: Human subcutaneous adipose tissue shows site-specific differences in fatty acid composition. Am J Clin Nutr 60: 725-729, 1994. 
PINNICK KE, NEVILLE MJ, FIELDING BA, FRAYN KN, KARPE F, HODSON L: Gluteofemoral adipose tissue plays a major role in production of the lipokine palmitoleate in humans. Diabetes 61: 1399-1403, 2012.

ROBERTS R, HODSON L, DENNIS AL, NEVILLE MJ, HUMPHREYS SM, HARNDEN KE, MICKLEM KJ, FRAYN KN: Markers of de novo lipogenesis in adipose tissue: associations with small adipocytes and insulin sensitivity in humans. Diabetologia 52: 882-890, 2009.

SAMPATH H, NTAMBI JM: The fate and intermediary metabolism of stearic acid. Lipids 40: 1187-1191, 2005.

SAMPATH H, MIYAZAKI M, DOBRZYN A, NTAMBI JM: Stearoyl-CoA desaturase-1 mediates the pro-lipogenic effects of dietary saturated fat. J Biol Chem 282: 2483-2493, 2007.

SARIS WH, HARPER A: DIOGenes: A multidisciplinary offensive focused on the obesity epidemic. Obes Rev 6: 175$176,2005$.

SJÖGREN P, SIERRA-JOHNSON J, GERTOW K, ROSELL M, VESSBY B, DE FAIRE U, HAMSTEN A, HELLENIUS ML, FISHER RM: Fatty acid desaturases in human adipose tissue: relationships between gene expression, desaturation indexes and insulin resistance. Diabetologia 51: 328-335, 2008.

STEFAN N, KANTARTZIS K, CELEBI N, STAIGER H, MACHANN J, SCHICK F, CEGAN A, ELCNEROVA M, SCHLEICHER E, FRITSCHE A, HÄRING HU: Circulating palmitoleate strongly and independently predicts insulin sensitivity in humans. Diabetes Care 33: 405-407, 2010.

STRABLE MS, NTAMBI JM: Genetic control of de novo lipogenesis: role in diet-induced obesity. Crit Rev Biochem Mol Biol 45: 199-214, 2010.

TRYGG J, WOLD S: Orthogonal projections to latent structure. J Chemometrics 16: 119-128, 2002.

TRYGG J, HOLMES E, LUNDSTEDT TJ: Chemometrics in metabonomics. J Proteome Res 6: 469-479, 2007.

YOKOZAWA J, SASAKI T, OHWADA K, SASAKI Y, ITO JI, SAITO T, KAWATA S: Down-regulation of hepatic stearoyl-CoA desaturase 1 expression by angiotensin II receptor blocker in the obese fa/fa Zucker rat: possible role in amelioration of insulin resistance and hepatic steatosis. J Gastroenterol 44: 583-591, 2009.

ZÁK A, TVRZICKÁ E, VECKA M, JÁCHYMOVÁ M, DUFFKOVÁ L, STANKOVÁ B, VÁVROVÁ L, KODYDKOVÁ J, ZEMAN M: Severity of metabolic syndrome unfavorably influences oxidative stress and fatty acid metabolism in men. Tohoku J Exp Med 212: 359-371, 2007.

ZHOU YE, EGELAND GM, MELTZER SJ, KUBOW S: The association of desaturase 9 and plasma fatty acid composition with insulin resistance-associated factors in female adolescents. Metabolism 58: 158-166, 2009. 